\title{
Association Between IL1B and SCN1A Polymorphism and Febrile Seizures in Children in Siberia
}

\author{
Maria A. Stroganova, $\mathrm{MD}^{1}$; Diana V. Dmitrenko, $\mathrm{PhD}, \mathrm{ScD}^{1}$; Ivan P. Artyukhov, $\mathrm{PhD}, \mathrm{ScD}^{1}$; \\ Svetlana N. Zobova, $\mathrm{PhD}^{1,2}$; Galina P. Martynova, $\mathrm{PhD}, \mathrm{ScD}^{1}$; Natalia A. Shnayder, $\mathrm{PhD}, \mathrm{ScD}^{* 1}$; \\ Anna V. Dyuzhakova, MD ${ }^{1}$ \\ ${ }^{1}$ V.F. Voyno-Yasenetsky Krasnoyarsk State Medical University \\ ${ }^{2}$ Scientific Research Institute of Medical Problems of the North \\ Krasnoyarsk, The Russian Federation
}

\begin{abstract}
Background: Febrile seizures (FS) are a benign, age-dependent, genetically determined state, in which the child's brain is susceptible to epileptic seizures occurring in response to hyperthermia. We assessed whether polymorphisms of ILIB and SCNIA genes, encoding the proinflammatory cytokine IL1B and SCN1A, respectively, could help to predict FS development and find a new way to treat FS.

Methods: We examined 121 children with FS and 30 children with hyperthermia syndrome (HTS) aged from 3 to 36 months. SNPs rs1143634 and rs16944 of IL1B gene, and rs3812718 and rs16851603 of SCN1A gene were determined by quantitative realtime PCR.

Results: The analysis for rs 1143634 revealed an association between the $C C$ genotype and increased risk of FS development (OR 6.56; $\mathrm{P}=0.0008$ ) against the background of acute respiratory viral infection. The same result was obtained for rs 16944 (OR 3.13 ; $\mathrm{P}=0.04$ ) and an association of two homozygous genotypes $C C / C C$. For rs3812718, the carriage of heterozygous genotype $C T$ demonstrated a direct relationship with FS development (OR 44.95; $\mathrm{P}=0.000$ ).

Conclusion: Children with high FS risk need preventive treatment and joint observation of a pediatrician, pediatric infectionist, and a neurologist-epileptologist. (International Journal of Biomedicine. 2017;7(2):96-103.)
\end{abstract}

Key Words: febrile seizures •ILIB gene •SCN1A gene • single nucleotide polymorphisms

\section{Abbreviations}

CNS, central neural system; GEFS+, generalized epilepsy with febrile seizures plus; EDTA, ethylenediaminetetraacetic acid; GABA, gamma aminobutyric acid; HWE, Hardy-Weinberg equilibrium; HHV-6, human herpes virus type 6; HSV, herpes simplex virus; HTS, hyperthermia syndrome; IL1RA, interleukin1 receptor antagonist; IL1B, interleukin-1 beta; PCR-RT, polymerase chain reaction real time; SCN1A, sodium voltage-gated channel alpha subunit 1; SNPs, single nucleotide polymorphisms.

\section{Introduction}

Febrile seizures (FS) are a benign, age-dependent, genetically determined state, in which the child's brain is

*Corresponding author: Prof. Natalia A. Shnayder, PhD, $S c D$; Head of the Neurological Center of Epileptology, Neurogenetics and Brain Research of the University Clinic of V.F. Voino-Yasenetsky Krasnoyarsk State Medical University. Krasnoyarsk, The Russian Federation.E-mail: nataliashnayder@gmail.com susceptible to epileptic seizures occurring in response to hyperthermia. FS are the most common variant of paroxysmal states in pediatric practice. FS are a transient condition but may be considered as the debut of the different epileptic syndromes. FS prevalence in the pediatric population is $2 \%$ $5 \%$ but there is an increased rate in some of geographic regions where it reaches $14 \%$. $^{(1)}$

Despite the widespread occurrence of FS in childhood, the reasons for their development are still subject to debate. 
Many authors believe that along with such factors as perinatal CNS damage and infectious diseases, the development of FS occurs as a result of the instability and immaturity of neuronal membranes. Indeed, in childhood the membrane of the CNS neuron becomes easily susceptible to the pathological effect of elevated temperature and, thus, reacts by violating the structure and functional properties, which can contribute to epileptogenesis. ${ }^{(2)}$ On the other hand, the development of FS can be genetically determined. ${ }^{(3)}$

The family history is one of the important risk factors in the development of FS - the more relatives have suffered or are suffering from a given state, the higher is the risk of developing FS in the proband and siblings. Earlier research confirms the relationship between family susceptibility and a high risk of developing FS. As shown, a positive family history of FS can be found in $25 \%-40 \%$ of patients. ${ }^{(4)}$

FS are a multifactorial disease whose implementation depends on other genes (modifying the course of FS) as well as environmental factors. Recent studies show that the differences in the genes that control defensive reactions of the organism can affect the level of production of the encoded proteins and, thereby, the character of immune response. ${ }^{(5)}$ In this regard, a functional polymorphism of cytokine genes is of great interest, since these proteins contribute most to the regulation of immunity, in epilepsy as well. ${ }^{(6-8)}$ The most frequent causes of differences in gene structure are point mutations, tandem repeats of parts of the gene, and deletions of nucleotides or small gene fragments. The mutant fragments of one or several genes, located very close to each other, can be inherited together (coupling) as the result of selective advantages or, more typically, because of the irregularities of meiotic recombination in this chromosomal region. ${ }^{(5-7)}$ Multiple animal studies have shown that the components of the immune response can play some role in FS pathogenesis.

On the other hand, the analysis of data found in the literature has shown that the development of generalized forms of epilepsy, both with and without FS - including the formation of pharmacoresistant forms and adverse drug reactions related to the administration of sodium channel blockers, as well as the development of medial temporal sclerosis - can be associated with polymorphism $\mathrm{rs} 3812718(166909544 C>T)$ of SCN1A gene encoding SCN1A. Nevertheless, we have not found studies of the association of this polymorphism with FS development in young children in the available literature, although there are reports of the possible association of this polymorphism with the risk of GEFS + development. ${ }^{(3,9)}$

Based on these findings, one can suppose that polymorphisms of $I L 1 B$ and SCN1A genes, encoding the proinflammatory cytokine IL1B and SCN1A, respectively, are one of the factors that can help determine FS development and further help in finding a new way of FS treatment. ${ }^{(10)}$ The aim of the study was the investigation of frequency for high-producing alleles of the IL1B- and SCN1A genes polymorphisms in children with FS.

\section{Material and Methods} Patients

Our investigation was observational, continued (retrospective, prospective), and case-control designed. The study was approved by the Ethics Committee of V.F. VoynoYasenetsky Krasnoyarsk State Medical University (Protocol №52/2013 from 27.11.2013). All patients were included in the present study after a voluntary informed consent was signed by legal representatives of a child (parents or guardians). Patients were enrolled in accordance with methods of stratified randomization using inclusion and exclusion criteria. The inclusion criteria were typical FS against the background of acute respiratory infection; both genders; age 3-36 months; Caucasian race; place of residence - Krasnoyarsk. The exclusion criteria were age under 3 months and older 3 years, acute neuroinfection, atypical FS, epilepsy or epileptical syndromes, and congenital brain malformations or cerebral palsy.

A total of 151 children were examined. The main group consisted of 121 children (73 males and 48 females) between the ages of 3 and 36 months. All children were hospitalized in the Krasnoyarsk inter-district children's hospital \#1 with acute respiratory viral infection (ARVI), complicated by FS, for the period from October 2013 to September 2014. The control group consisted of 30 children (10 males and 20 females) with HTS against the background of ARVI without FS in anamnesis.

\section{The study of etiological structure of FS}

Along with routine methods of laboratory diagnostics, we detected for all patients the markers of influenza virus, adenovirus, parainfluenza virus, and for randomly selected 62 patients from the main group, the markers of herpesvirus infection (HSV types 1 and 2, CMV, and HHV-6). Specific classes of IgG and IgM in blood serum with determination of the avidity index were revealed by immunosorbent assay (ELISA; "Vector-best", Russia) using a chemistry analyzer STAT FAX 3300 (Awareness Technology, USA). DNA of listed viruses was detected in blood, urine, and nasopharyngeal mucus by PCR-RT.

\section{Detection of ILIB and SCN1A genes polymorphisms by PCR-RT}

From each patient, $2 \mathrm{~mL}$ of peripheral blood were drawn into an EDTA tube. Genomic DNA was extracted from $0.15 \mathrm{~mL}$ samples by using a DNA-sorb-B kit (K1-2-100-CE, AmpliSens), according to the manufacturer's instructions. Two SNPs for $I L 1 B$ gene rs1143634 (c.3954C $>T$ ) and rs16944 $(c .-511 C>T)$ and two SNPs for SCN1A gene rs3812718 $(166909544 C>T)$ and $\operatorname{rs} 16851603(166991436 C>T)$ were determined by quantitative real-time PCR using "Rotor-Gene 6000" (Corbet Life Science, Australia). Genotyping was performed using TaqMan allele discrimination technology and commercially available TaqMan probes (Applied Biosystems, USA). PCR master mix contained $2.5 \mathrm{x}$ reaction mix for PCR-RT, $25 \mathrm{mM} \mathrm{MgCl}$, dd $\mathrm{d}_{2} \mathrm{O}$ (M-428; Syntol). PCR-RT conditions were as following: $95^{\circ} \mathrm{C}-10 \mathrm{~min} ; 92^{\circ} \mathrm{C}-15 \mathrm{c}$, $60^{\circ} \mathrm{C}-90 \mathrm{c}$ ( 40 cycles). To designate the genotype variants, the following designations were taken: homozygous lowproducing genotype - TT (thymine/thymine), heterozygous genotype for high-producing allele - $C T$ (cytosine/thymine), 
homozygous genotype for high-producing allele - CC (cytosine/cytosine).

Statistical analysis was performed using STATISTICA 7.0 (StatSoft, USA) and SPSS 22.0. Baseline characteristics were summarized as frequencies and percentages for categorical variables and as mean $\pm \mathrm{SD}$ for continuous variables. The genotype frequency distribution for each variant was separately tested for Hardy-Weinberg equilibrium (HWE) with a chi-square test in the patient and control groups. Odds ratios (OR) and 95\% confidence intervals (CI) were calculated. A probability value of $P<0.05$ was considered statistically significant.

\section{Results}

\section{Description of population}

The main group of patients (mean age, $21.69 \pm 10.32$ months) with FS consisted of $60.3 \%$ boys and $39.7 \%$ girls. The control group (mean age, $14.63 \pm 8.24$ months) consisted of $66.7 \%$ girls and $33.3 \%$ boys. For the main group, the first FS episode was determined in $57.9 \%$ of examined patients, whereas in $42.1 \%$ of children there was a recurrent course of FS. Boys were predominant over girls among patients with recurrent FS. Interestingly, the greatest number of FS patients $(80.2 \%)$ was registered at the age of more than 12 months, and in $13.2 \%$ of cases, the debut of FS development occurred at the age of 36 months. Studying the family history, we have found that $31.4 \%$ of FS children had a genetic predisposition. Thus, FS at the age up to 3 years were observed in proband's parents in $28.9 \%$ of cases, and a family history of epilepsy in $2.5 \%$ of the children. However, in view of the lack of information about hereditary anamnesis, since the vast majority of parents $(98.3 \%)$ could not clarify the data of the family history of FS in the pedigree of more than the second generation, one can only assume that the contribution of genetic predisposition to FS development in examined children was significantly higher. Studying the history, we did not discover any statistically significant differences in the influence of perinatal factors between the comparison groups. For the main group, the frequency of ARVI reached 4-5 or more episodes per year in $68.6 \%$ of children, whereas in the control group the number of ARVI episodes did not exceed 4-5 per year $(\mathrm{P}<0.05)$.

\section{The study of etiological structure of FS}

All patients from the main and control groups were examined using serological tests to identify the etiology of the disease. ARVI was revealed in $86.8 \%$ of patients from the main group, and only $13.2 \%$ of children had no markers of viral infection according to available diagnostic methods. Etiological structure of ARVI in the main group was represented by the following pathogens with a statistically insignificant difference within the group $(\mathrm{p}>0.05)$ : influenza A (H3N2) virus was found in $37.2 \%(45 / 121)$ of patients, human orthopneumovirus was registered in $23.1 \%(28 / 121)$ of cases, adenovirus was determined in $12.4 \%(15 / 121)$, and parainfluenza virus type 2 caused the disease in $14.0 \%$ (17/121) of children with FS.

In the control group, respiratory virus markers were determined in $83.3 \%(25 / 30)$ of cases, particularly, human orthopneumovirus was identified in $46.7 \%$ (14/30) of children, adenovirus and parainfluenza virus type 2 were revealed in $30.0 \%(9 / 30)$ and $6.7 \%(2 / 30)$ of patients, respectively, and in $16.7 \%(5 / 30)$ of cases, the markers of a viral infection were not detected.

In addition, 62(51.2\%) randomly selected children from the main group (54.8\% (34/62) of children with the first FS episode and $45.2 \%(28 / 62)$ of patients with recurrent course of FS) were tested for the presence of herpesvirus markers. Markers of one, two, and more representatives of herpes viruses were revealed in $48.4 \%, 24.2 \%$, and $6.5 \%$ of examined children, respectively.

High titers of IgG antibodies to HHV-6 were identified in $38.7 \%(24 / 62)$ of children having herpesviruses markers, and the optical density of samples was up to $1.07 \pm 0.38$ (critical $\mathrm{OD}=0.333$ ). IgG antibodies against HHV-6 were determined in $46.4 \%(13 / 28)$ of examined patients with recurrent FS, more often than antibodies against other investigated herpes viruses.

Serum IgG antibodies against HSV-1 and 2 were found in high titers in $17.7 \%(11 / 62)$ of herpesvirus carriers. The avidity index of antibodies against HSV-1 and 2 was $87.25 \pm 14.76 \%$, indicating the prolonged persistence of the virus in the child's organism. At the same time, DNA of HSV1 and 2 was detected in nasopharyngeal mucus in only $3.2 \%$ $(2 / 62)$ of FS patients. However, the absence of DNA of HSV-1 and 2 in nasopharyngeal mucus cannot be taken to mean that the virus is absent in the organism. It is also important to note, that the persistence of HSV-1 and 2 was observed in $35.7 \%$ $(10 / 28)$ of examined children with recurrent course of FS.

The IgG antibodies against CMV were detected in high titers in serum of $46.8 \%(29 / 62)$ of FS patients. Anti-CMVIgG avidity index was $83.2 \pm 7.61 \%$ that indicated a prolong persistence of the pathogen. The exacerbation of CMVinfection was determined in $10.3 \%(3 / 29)$ of children with CMV markers, while the avidity index turned out to be equal to $81.1 \pm 3.2 \%$. Only $3.4 \%(1 / 29)$ of patients had low-avidity antibodies, confirming early and acute courses of CMVinfection. The CMV DNA was detected in the urine of $24.2 \%$ $(15 / 62)$ of examined children, and in $4.8 \%(3 / 62)$ of them the IgM antibodies were found in serum together with CMV DNA, indicating an acute CMV-infection. Among all CMV carriers, the first FS episode was observed in 58.6\% (17/29) of cases, other patients $(41.4 \% ; 12 / 29)$ had a recurrent course of FS.

\section{ILIB gene polymorphisms distribution}

Studying SNPs markers rs16944 $(-511 C>T)$ and rs1143634 $(3954 C>T)$ of $I L 1 B$ gene, we have found the prevalence of homozygous and heterozygous genotypes over high-producing allele $C$ in both comparison groups, and the frequency of the heterozygous genotype was statistically significantly higher in the control group (children with HTR) $(\mathrm{P}<0.05)$ (Table 1).

Analysis of allele frequency for rs $16944(-511 C>T)$ has shown that in the main group the frequency of allele $C$ (wild type) was statistically significantly higher: $69.8 \%$ compared to $55.0 \%$ in the control group ( $\mathrm{OR}=1.89,95 \% \mathrm{CI}: 1.06-3.38$; 
$\mathrm{P}=0.03$ ). At the same time, the frequency of allele $T$ in the main group was statistically lower: $30.2 \%$ versus $45.0 \%$ in the control group (OR=0.53, 95\% CI: 0.30-0.94; $\mathrm{P}=0.03)$.

For allele frequency of rs1143634 (3954C>T), a statistically significant prevalence of high-producing allele $C(70.2 \%$ versus $50.0 \%)$ was found in the main group $(\mathrm{OR}=2.36,95 \% \mathrm{CI}: 1.33-4.20 ; \mathrm{P}=0.003)$. On the contrary, the frequency of low-producing allele $T$ was significantly higher in the control group compared to the main one $(50.0 \%$ versus $29.8 \% ; \mathrm{OR}=0.42,95 \% \mathrm{CI}: 0.24-0.75 ; \mathrm{P}=0.003)$. Based on these findings, the carriage of allele $C$ can be considered as a risk factor for FS formation for both SNPs (rs16944 and rs1143634).

Table 1.

Gender-specific genotype distribution of ILIB gene polymorphisms in the main and control groups.

\begin{tabular}{|c|c|c|c|c|c|c|c|}
\hline \multirow{3}{*}{ SNP } & \multirow{3}{*}{ Genotype } & \multicolumn{3}{|c|}{ Main group } & \multicolumn{3}{|c|}{ Control group } \\
\hline & & \multicolumn{2}{|c|}{ Gender, n (\%) } & \multirow{2}{*}{ 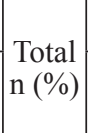 } & \multicolumn{2}{|c|}{ Gender, n (\%) } & \multirow{2}{*}{$\begin{array}{l}\text { Total } \\
\text { n }(\%)\end{array}$} \\
\hline & & $\begin{array}{c}\text { Males } \\
\mathrm{n}=73\end{array}$ & $\begin{array}{c}\text { Females } \\
n=48\end{array}$ & & $\begin{array}{c}\text { Males } \\
n=10\end{array}$ & $\begin{array}{c}\text { Females } \\
n=20\end{array}$ & \\
\hline \multirow{3}{*}{$\begin{array}{l}\text { rs16944 } \\
(-511 \mathrm{C}>\mathrm{T})\end{array}$} & $\mathrm{CC}^{*}$ & $\begin{array}{c}32 \\
(43.8)\end{array}$ & $\begin{array}{c}27 \\
(56.2)\end{array}$ & $\left|\begin{array}{c}59 \\
(48.8)\end{array}\right|$ & $\begin{array}{c}2 \\
(20.0)\end{array}$ & $\begin{array}{c}5 \\
(25.0)\end{array}$ & $\begin{array}{c}7 \\
(23.3)\end{array}$ \\
\hline & $\mathrm{CT}^{*}$ & $\begin{array}{c}37 \\
(50.7)\end{array}$ & $\begin{array}{c}14 \\
(29.2)\end{array}$ & $\mid \begin{array}{c}51 \\
(42.1)\end{array}$ & $\begin{array}{c}6 \\
(60.0)\end{array}$ & $\begin{array}{c}13 \\
(65.0)\end{array}$ & $\begin{array}{c}19 \\
(63.3)\end{array}$ \\
\hline & $\mathrm{TT}^{*}$ & $\begin{array}{c}4 \\
(5.5)\end{array}$ & $\begin{array}{c}7 \\
(14.6)\end{array}$ & $\begin{array}{c}11 \\
(9.1)\end{array}$ & $\begin{array}{c}2 \\
(20.0)\end{array}$ & $\begin{array}{c}2 \\
(10.0)\end{array}$ & $\begin{array}{c}4 \\
(13.3)\end{array}$ \\
\hline \multirow{3}{*}{$\begin{array}{l}\text { rs1143634 } \\
(3954 C>T)\end{array}$} & $\mathrm{CC}^{*}$ & $\begin{array}{c}33 \\
(45.2)\end{array}$ & $\begin{array}{c}18 \\
(37.5)\end{array}$ & $\mid \begin{array}{c}51 \\
(42.1)\end{array}$ & $\begin{array}{c}1 \\
(10.0)\end{array}$ & $\begin{array}{c}2 \\
(10.0)\end{array}$ & $\begin{array}{c}3 \\
(10.0)\end{array}$ \\
\hline & $\mathrm{CT}^{*}$ & $\begin{array}{c}39 \\
(53.4)\end{array}$ & $\begin{array}{c}29 \\
(60.4)\end{array}$ & $\mid \begin{array}{c}68 \\
(56.2)\end{array}$ & $\begin{array}{c}8 \\
(80.0)\end{array}$ & $\begin{array}{c}16 \\
(80.0)\end{array}$ & $\begin{array}{c}24 \\
(80.0)\end{array}$ \\
\hline & $\mathrm{TT}^{*}$ & $\begin{array}{c}1 \\
(1.4)\end{array}$ & $\begin{array}{c}1 \\
(2.1)\end{array}$ & $\begin{array}{c}2 \\
(1.7)\end{array}$ & $\begin{array}{c}1 \\
(10.0)\end{array}$ & $\begin{array}{c}2 \\
(10.0)\end{array}$ & $\begin{array}{c}3 \\
(10.0)\end{array}$ \\
\hline
\end{tabular}

* - P<0.05 for total genotype frequency between the main and control groups

Analyzing the genotype distribution for SNP rs16944 $(-511 C>T)$, we have shown statistically significant differences between the main and control groups, according to the multiple inheritance model $\left(\chi^{2}=6.32, \mathrm{P}=0.04\right)$. Thus, the carriage of homozygous genotype $C C$ demonstrated a direct relationship with the probability of an outcome, which in our study was FS development (OR=3.13, 95\% CI: $1.25-7.83 ; \mathrm{P}=0.04)$. On the contrary, the carriage of heterozygous genotype $C T$ can be considered as a protective factor $(\mathrm{OR}=0.42,95 \% \mathrm{CI}$ : 0.18 $0.96 ; \mathrm{P}=0.04$ ). The influence of the carriage of homozygous genotype $T T$ to FS development was not statistically significant $(\mathrm{OR}=0.65,95 \%$ CI: $0.19-2.21)$. In addition, the recessive inheritance model ( $C C$ vs. $C T+T T$ ) also showed significant differences in genotype distribution between comparison groups $\left(\chi^{2}=6.32, \mathrm{P}=0.01\right)$.

For SNP rs1143634 (3954C $>T)$, statistically significant differences between the main and control groups were determined according to the multiple inheritance model $\left(\chi^{2}=14.24, P=0.0008\right)$. The carriage of homozygous genotype
$C C$ was characterized by direct relationship with the high probability of FS development $(\mathrm{OR}=6.56,95 \%$ CI: 1.89 $22.80 ; \mathrm{P}=0.0008$ ), whereas the carriage of both heterozygous genotype $C T$ and homozygous genotype $T T$ can be considered as protective factors $(\mathrm{OR}=0.32,95 \% \mathrm{CI}: 0.12-0.84$ for $C T$; $\mathrm{OR}=0.15,95 \%$ CI: $0.02-0.95$ for $T T ; \mathrm{P}=0.0008$ ).

We determined the HWE was stable in carriers of $I L 1 B$ gene polymorphism $(c .-511 C>T)$ in the main group and moderate in the control one $\left(\chi^{2}=0.00, p>0.05\right.$ for the main group; $\chi^{2}=2.34, \mathrm{P}>0.05$ for the control group). At the same time, in the group of children with FS and the control group the unstable HWE of IL1B gene polymorphism (c.3954C $>T)$ genotypes was indicated $\left(\chi^{2}=14.36, \mathrm{P}<0.05\right.$ for the main group; $\chi^{2}=10.8, p<0.05$ for the control group). Thus, if all the conditions of genetic equilibrium are kept, in subsequent generations it will be possible to observe the stable carrier state $(c .-511 C>T)$ of polymorphism genotypes and thus predict the outcome of the disease.

Interesting data were obtained by studying the associations of polymorphic allelic variants (c.-511C $>T$, c. $3954 C>T$ ) for $I L 1 B$ gene (Table 2). We have shown that $14.9 \%(18 / 121)$ of FS children were homozygous carriers of the association of genotypes on two high-producing $I L 1 B$ gene allelic variants $(-511 C C / 3954 C C)$, and the frequency of this association was higher in boys $(66.7 \%)$ than in girls $(33.3 \%)$, but gender differences did not reach statistical significance (Table 2, Fig.1). In the control group, the association of homozygous variants was not detected. It is also noted that in the group of patients who were carriers of the $-511 C C / 3954 C C$ association, the recurrent course of FS was observed more frequently than the first episode of FS $(61.1 \%$ $(11 / 18)$ vs. $38.9 \%(7 / 18), \mathrm{P}<0.05)$, and the disease proceeded against the background of exacerbation of the latent form of CMV-infection (mean avidity index was $70.8 \pm 2.5 \%$ ).

\section{Table 2.}

The frequency of associations of polymorphic allelic variants for $I L 1 B$ gene in the main and control groups.

\begin{tabular}{|c|c|c|c|c|c|c|c|c|c|}
\hline \multirow{2}{*}{ 气े } & \multicolumn{9}{|c|}{$\begin{array}{c}\text { Association of polymorphic allelic variants for IL-1 } \beta \text { gene } \\
\text { rs16944 (c.-511C }>\text { T) / rs1143634 (c.3954C }>\mathrm{T}) \\
\mathrm{n}(\%)\end{array}$} \\
\hline & $\mathrm{CC} / \mathrm{CC}$ & $\mathrm{CC} / \mathrm{CT}$ & $\mathrm{CC} / \mathrm{TT}$ & $\mathrm{CT} / \mathrm{CC}$ & $\mathrm{CT} / \mathrm{CT}$ & $\mathrm{CT} / \mathrm{T}^{\prime}$ & $\mathrm{T}$ TT/CT & $\mathrm{TT} / \mathrm{CC}$ & $\mathrm{TT} / \mathrm{TT}$ \\
\hline MC & $\left(\begin{array}{c}18 \\
(14.9) *\end{array}\right.$ & $\left(\begin{array}{c}39 \\
(32.2)\end{array}\right.$ & $\begin{array}{c}2 \\
(1.6)\end{array}$ & $\mid \begin{array}{c}29 \\
(24.0)\end{array}$ & * $\quad \begin{array}{c}20 \\
(18.2)\end{array}$ & $\begin{array}{c}0 \\
(0.0)\end{array}$ & $\begin{array}{c}0 \\
(0.0)\end{array}$ & $\begin{array}{c}4 \\
(3.3)\end{array}$ & $\left(\begin{array}{c}7 \\
(5.8) *\end{array}\right.$ \\
\hline $\mathrm{CG}$ & $\begin{array}{c}0 \\
(0.0)\end{array}$ & $\begin{array}{c}7 \\
(23.3)\end{array}$ & $\begin{array}{c}0 \\
(0.0)\end{array}$ & $\begin{array}{c}3 \\
(10.0)\end{array}$ & $\begin{array}{c}11 \\
(36.7)\end{array}$ & $\begin{array}{c}0 \\
(0.0)\end{array}$ & $\begin{array}{c}5 \\
(16.7)\end{array}$ & $\begin{array}{c}4 \\
(13.3)\end{array}$ & $\begin{array}{c}0 \\
(0.0)\end{array}$ \\
\hline
\end{tabular}

$M G$ - Main group; $C G$ - Control group; * $-P<0.05$ vs. the control group

In the main group, the $-511 C C / 3954 C T$ association occurred in $32.2 \%$ of children, and the numbers of boys and girls were approximately equal. In the control group, the frequency of this association did not exceed $23.3 \%$ with statistically significant prevalence among girls $(71.4 \%), \mathrm{P}<0.05)$. The frequencies of $-511 C T / 3954 C C$ and $-511 C T / 3954 C T$ associations were up to $24.0 \%$ and $18.2 \%$, 
respectively, with a statistically significant predominance of boys in the group of patients with FS development. In the control group, there was a predominance of these associations among girls $(\mathrm{P}<0.05)$ (Table 2, Fig.1). At the same time, the frequency of homozygous carriers of the association of lowproducing allelic variants $(-511 T T / 3954 T T)$ in children with FS was low (5.1\%), and more frequent in girls than in boys; gender differences did not reach statistical significance. It is important to note, that in the control group the association of low-producing allelic variants $(-511 T T / 3954 T T)$ was not observed (Fig. 1).

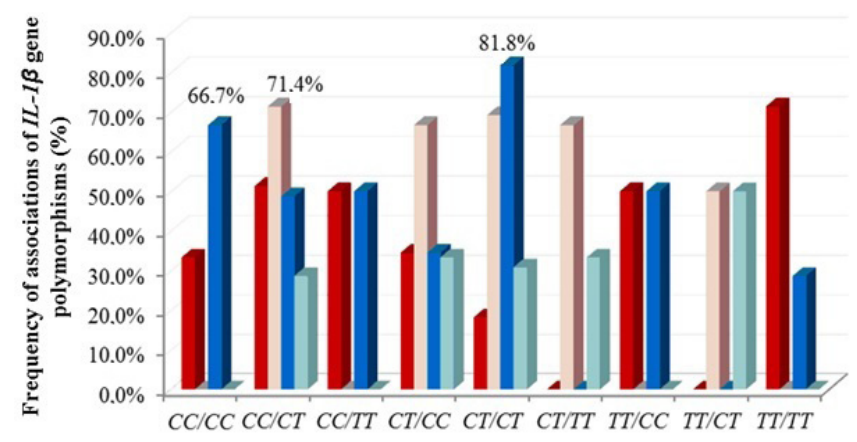

- Females with FS $=$ Females with HTS $\mid$ Males with FS $=$ Males with HTS

Fig. 1. Gender-specific distribution of frequency of ILIB gene polymorphisms (rs16944 [c.-511C>T] and rs1143634 [c.3954C>T]) in two groups.

In the study of the relationship between the persistence of herpes viruses and the presence of polymorphisms of the gene $I L 1 B$ in young children with FS, it was found that the persistence of CMV-infection was most frequently revealed in the carriers of homozygous genotype for high-producing allelic variant 3954CC (Table 3). In general, observed children with FS were characterized by a predominance of homozygous genotype on high-producing polymorphic allelic variants of the $I L 1 B$ gene in association with herpesviruses persistence.

Table 3.

The frequency of herpes virus persistence and Il1B genotypes in children with FS $(n=62)$

\begin{tabular}{|l|c|c|c|c|c|c|}
\hline \multirow{4}{*}{ Herpesvirus } & \multicolumn{3}{|c|}{$\begin{array}{c}\text { rs1143634 } \\
\text { (c.3954C>T) } \\
\text { n (\%) }\end{array}$} & \multicolumn{3}{c|}{ rs16944 (c.-511C>T) } \\
& CC $(\%)$ \\
\cline { 2 - 7 } & $\mathrm{CT}$ & $\mathrm{TT}$ & $\mathrm{CC}$ & $\mathrm{CT}$ & $\mathrm{TT}$ \\
\hline HSV-1 and 2 & $\begin{array}{c}2 \\
(3.2)\end{array}$ & $\begin{array}{c}0 \\
(0.0)\end{array}$ & $\begin{array}{c}2 \\
(3.2)\end{array}$ & $\begin{array}{c}1 \\
(1.6)\end{array}$ & $\begin{array}{c}0 \\
(0.0)\end{array}$ & $\begin{array}{c}0 \\
(0.0)\end{array}$ \\
\hline CMV & $\begin{array}{c}20 \\
(32.3)\end{array}$ & $\begin{array}{c}12 \\
(19.4)\end{array}$ & $\begin{array}{c}0 \\
(0.0)\end{array}$ & $\begin{array}{c}18 \\
(29.0)\end{array}$ & $\begin{array}{c}10 \\
(16.1)\end{array}$ & $\begin{array}{c}2 \\
(3.2)\end{array}$ \\
\hline HHV-6 & $\begin{array}{c}11 \\
(17.7)\end{array}$ & $\begin{array}{c}15 \\
(24.2)\end{array}$ & $\begin{array}{c}0 \\
(0.0)\end{array}$ & $\begin{array}{c}16 \\
(25.8)\end{array}$ & $\begin{array}{c}12 \\
(19.4)\end{array}$ & $\begin{array}{c}3 \\
(4.8)\end{array}$ \\
\hline $\begin{array}{l}\text { Mixt-persistence } \\
\text { (IgG to 2 and more } \\
\text { herpesviruses) }\end{array}$ & $\begin{array}{c}9 \\
(14.5)\end{array}$ & $\begin{array}{c}7 \\
(11.3)\end{array}$ & $\begin{array}{c}1 \\
(1.6)\end{array}$ & $\begin{array}{c}8 \\
(12.9)\end{array}$ & $\begin{array}{c}7 \\
(11.3)\end{array}$ & $\begin{array}{c}2 \\
(3.2)\end{array}$ \\
\hline
\end{tabular}

The results allowed us to form a group of those at risk of FS development that depends on the presence of polymorphic allelic variants of the $I L 1 B$ gene (Table 4), which is important both for dispensary observation of children with FS and for treatment and prevention tactics. Thus, the management tactics for the children with FS, from the viewpoint of a personalized approach, should be different.

\section{Table 4.}

Recurrent FS risk groups depending on the IL1B gene allelic variants.

\begin{tabular}{|l|l|}
\hline \multicolumn{1}{|c|}{ Degree of risk } & \multicolumn{1}{|c|}{ Group characteristics } \\
\hline Low-risk group & $\begin{array}{l}\text { Children having association of homozygous } \\
\text { genotypes on two low-producing allelic } \\
\text { variants (-511TT/3954TT) of IL1 } \beta \text { gene } \\
\text { polymorphisms }\end{array}$ \\
\hline Moderate-risk group & $\begin{array}{l}\text { Children having association of heterozygous } \\
\text { genotypes on one (-511CT or 3954CT) or } \\
\text { two allelic variants (-511CT/3954CT) of } \\
\text { IL1 } \beta \text { gene polymorphisms }\end{array}$ \\
\hline High-risk group & $\begin{array}{l}\text { Children having association of of } \\
\text { homozygous genotypes on one (-511CC } \\
\text { or 3954CC) or two high-producing allelic } \\
\text { variants (-511CC/3954CC) of IL1 } \beta \text { gene } \\
\text { polymorphisms }\end{array}$ \\
\hline
\end{tabular}

\section{SCN1A gene polymorphisms distribution}

Analyzing the genotype frequency of SCN1A gene polymorphisms, we determined the prevalence of heterozygous genotypes with statistically significant differences between groups $(\mathrm{P}<0.05)$ (Table 5).

Table 5.

The genotype frequency of SCN1A gene polymorphisms in the main and control groups.

\begin{tabular}{|c|c|c|c|c|}
\hline SNP & Genotype & $\begin{array}{c}\text { Main group } \\
\text { n (\%) }\end{array}$ & $\begin{array}{c}\text { Control group } \\
\text { n (\%) }\end{array}$ & P value \\
\hline \multirow{3}{*}{ rs3812718 } & CC & $2(1.7)$ & $15(50.0)$ & \\
\cline { 2 - 4 } & CT & $118(97.5)$ & $14(46.7)$ & \multirow{2}{*}{$\mathrm{P}<0.05$} \\
\cline { 2 - 4 } & $\mathrm{TT}$ & $1(0.8)$ & $1(3.3)$ & \\
\hline \multirow{3}{*}{ rs16851603 } & $\mathrm{CC}$ & $27(22.3)$ & $10(33.3)$ & \multirow{2}{*}{$\mathrm{P}>0.05$} \\
\cline { 2 - 4 } & $\mathrm{CT}$ & $86(71.1)$ & $20(66.4)$ & \\
\cline { 2 - 4 } & $\mathrm{TT}$ & $8(6.6)$ & $0(0.0)$ & \\
\hline
\end{tabular}

Analyzing the allele distribution for rs 3812718 , we have shown that in the main group the frequency of allele $C$ (wild type) was statistically significantly lower and constituted to $50.4 \%$ compared to $73.3 \%$ in the control group $(\mathrm{OR}=0.37$, 95\% CI: $0.20-0.69 ; \mathrm{P}=0.001)$. At the same time, the frequency of low-producing mutant allele $T$ in the main group was statistically significantly higher and made up $49.6 \%$ versus $26.7 \%$ in the control group $(\mathrm{OR}=2.70,95 \% \mathrm{CI}: 1.45-5.05$; $\mathrm{P}=0.001$ ). 
For allele frequency of rs16851603, insignificant prevalence of allele $C(66.7 \%$ versus $57.9 \%)$ was found in the control group (OR=0.69, 95\% CI: $0.38-1.24 ; \mathrm{P}>0.05)$. The frequency of mutant allele $T$ was insignificantly higher in the main group compared to the control one ( $42.1 \%$ versus $33.3 \%$; $\mathrm{OR}=1.46,95 \%$ CI: 0.80-2.64; $\mathrm{P}>0.05$ ).

Analyzing the genotype distribution for SNP rs3812718, we have determined high statistically significant differences between the main and control groups according to the multiple inheritance model $\left(\chi^{2}=58.16, \mathrm{P}=0.000\right)$. Thus, the carriage of heterozygous genotype $C T$ demonstrated a direct relationship with the probability of an outcome, which in our study was FS development $(\mathrm{OR}=44.95,95 \% \mathrm{CI}: 11.63-173.73$; $\mathrm{P}=0.000)$. On the contrary, the carriage of homozygous genotype $C C$ can be considered as a protective factor (OR $=0.02,95 \% \mathrm{CI}$ : 0.00 $0.08 ; \mathrm{P}=0.000$ ). The influence of the carriage of homozygous genotype $T T$ to FS development was not statistically significant $(\mathrm{OR}=0.24,95 \%$ CI: $0.01-3.98)$.

For SNP rs16851603, we have not found statistically significant differences between the main and control groups according to the multiple inheritance model $\left(\chi^{2}=3.24, \mathrm{P}=0.2\right)$. OR and $95 \% \mathrm{CI}$ for the carriage of genotypes CC, CT, and TT were 0.57 and $0.24-1.37,1.23$ and $0.52-2.89$, and 4.57 and $0.26-81.39$, respectively.

The genotype distribution for SNP rs381271 $(166909544 C>T)$, located in the splice-donor site of SCN1A exon $5 \mathrm{~N}$, showed the stable HWE in the control group and unstable HWE in the main group $\left(\chi^{2}=109.33, \mathrm{P}<0.05\right.$ for the main group; $\chi^{2}=1.12, \mathrm{P}>0.05$ for the control group).. We also detected the unstable HWE for genotype frequencies of SNP rs16851603 (66991436C > T), located in the intron of SCN1A gene, both in the main group $\left(\chi^{2}=25.32, \mathrm{P}<0.05\right)$ and in the control group $\left(\chi^{2}=7.50, \mathrm{P}<0.05\right)$. Thus, if all the conditions of genetic equilibrium are kept, in subsequent generations it will be possible to observe the stable carrier state of studied SNPs and thereby predict the outcome of the disease.

Analyzing associations of genotypes of studied SCN1A gene polymorphisms, we determined a statistically significant prevalenceofassociationrepresented byhomozygousgenotypes over wild-type alleles (166909544CC/166991436CC) in the control group of $13.3 \%$ versus $1.7 \%$ in the main group $(\mathrm{P}<0.05)$. Moreover, in the main group this association was found only among girls (table 6). It was also noted that in the main group the frequency of association of homozygous genotypes by the $C$ allele (166909544CC/166991436CC) was insignificantly higher among children with the first episode of FS (1.7\%) compared to children with the recurrent FS course, and in children with a recurrent course of FS, the incidence of heterozygous genotypes was observed in more than a third of cases (38.8\%). In the main group, the genotype association (166909544CC/166991436CT) was not found in any case, while in the control group the frequency of this association was $20.0 \%(\mathrm{P}<0.05)$. The frequency of the $166909544 C T / 166991436 C C$ association among children with FS was $21.5 \%$, and the association of heterozygous genotypes (166909544CT/166991436CT) was determined in $70.2 \%$ of cases with a statistically significant prevalence among boys compared to girls ( $68.1 \%$ vs. $31.9 \%$, respectively,
$\mathrm{P}<0.05$ ) (Table 6). It should be noted that patients with the $166909544 C T / 166991436 C T$ association had the recurrent course of FS in $55.3 \%$ of cases. The association of homozygous genotypes by the $T$ allele (166909544TT/ 166991436TT) was not found in both comparison groups. However, the frequency of the 166909544TT/166991436CT association was significantly higher in the control group compared to the main one ( $23.3 \%$ vs. $0.8 \%$, respectively, $\mathrm{P}<0.05)$.

\section{Table 6.}

Gender-specific distribution of associations of polymorphic allelic variants for SCN1A gene in the main and control groups.

\begin{tabular}{|c|c|c|c|c|c|c|c|c|}
\hline \multirow{2}{*}{ 离 } & \multicolumn{8}{|c|}{$\begin{array}{c}\text { Association of polymorphic allelic variants of SCN1A gene } \\
\text { rs3812718 (166909544C }>\text { T) / rs 16851603 (66991436C }>\text { T) } \\
n(\%)\end{array}$} \\
\hline & $\mathrm{CC} / \mathrm{CC}$ & $\mathrm{CC} / \mathrm{CT}$ & $\mathrm{CT} / \mathrm{CC}$ & $\mathrm{CT} / \mathrm{CT}$ & $\mathrm{CT} / \mathrm{TT}$ & TT/CC & $\mathrm{TT} / \mathrm{CT}$ & \begin{tabular}{|l} 
TT/TT \\
CC/TT
\end{tabular} \\
\hline \multicolumn{9}{|c|}{ Main Group } \\
\hline $\mathrm{F}$ & $\begin{array}{c}2 \\
(1.7 \%)\end{array}$ & $\begin{array}{c}0 \\
(0.0 \%)\end{array}$ & $\begin{array}{c}12 \\
(9.9 \%)\end{array}$ & $\begin{array}{c}27 \\
(22.3 \%)\end{array}$ & $\begin{array}{c}6 \\
(5.0 \%)\end{array}$ & $\begin{array}{c}0 \\
(0.0 \%)\end{array}$ & $\begin{array}{c}1 \\
(0.8 \%)\end{array}$ & $\begin{array}{c}0 \\
(0 \%)\end{array}$ \\
\hline M & $\begin{array}{c}0 \\
(0.0 \%)\end{array}$ & $\begin{array}{c}0 \\
(0.0 \%)\end{array}$ & $\begin{array}{c}14 \\
(11.6 \%)\end{array}$ & $\begin{array}{c}58 \\
(47.9 \%)\end{array}$ & $\begin{array}{c}1 \\
(0.8 \%)\end{array}$ & $\begin{array}{c}0 \\
(0.0 \%)\end{array}$ & $\begin{array}{c}0 \\
(0.0 \%)\end{array}$ & $\begin{array}{c}0 \\
(0 \%)\end{array}$ \\
\hline 苞 & $\begin{array}{c}2 \\
(1.7 \%)^{*}\end{array}$ & $\left(\begin{array}{c}0 \\
(0.0 \%) *\end{array}\right.$ & $\begin{array}{c}26 \\
(21.5 \%)\end{array}$ & $\begin{array}{c}85 \\
(70.2 \%)^{*}\end{array}$ & $\begin{array}{c}7 \\
(5.8 \%)\end{array}$ & $\begin{array}{c}0 \\
(0.0 \%)^{*}\end{array}$ & $(0.8 \%)^{*}$ & $\begin{array}{c}0 \\
(0 \%)\end{array}$ \\
\hline \multicolumn{9}{|c|}{ Control group } \\
\hline $\mathrm{F}$ & $\begin{array}{c}2 \\
(6.7 \%)\end{array}$ & $\begin{array}{c}5 \\
(16.7 \%)\end{array}$ & $\begin{array}{c}2 \\
(6.7 \%)\end{array}$ & $\begin{array}{c}5 \\
16.7 \%\end{array}$ & $\begin{array}{c}0 \\
(0.0 \%)\end{array}$ & $\begin{array}{c}2 \\
(6.7 \%)\end{array}$ & $\begin{array}{c}4 \\
(13.3 \%)\end{array}$ & $\begin{array}{c}0 \\
(0 \%)\end{array}$ \\
\hline M & $\begin{array}{c}2 \\
(6.7 \%)\end{array}$ & $\begin{array}{c}1 \\
(3.3 \%)\end{array}$ & $\begin{array}{c}1 \\
(3.3 \%)\end{array}$ & $\begin{array}{c}2 \\
(6.7 \%)\end{array}$ & $\begin{array}{c}0 \\
(0.0 \%)\end{array}$ & $\begin{array}{c}1 \\
(3.3 \%)\end{array}$ & $\begin{array}{c}3 \\
(10.0 \%)\end{array}$ & $\begin{array}{c}0 \\
(0 \%)\end{array}$ \\
\hline 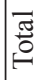 & $\begin{array}{c}4 \\
13.3 \%)\end{array}$ & $\begin{array}{c}6 \\
(20.0 \%)\end{array}$ & $\begin{array}{c}3 \\
(10.0 \%)\end{array}$ & $\begin{array}{c}7 \\
(23.3 \%)\end{array}$ & $\begin{array}{c}0 \\
(0.0 \%)\end{array}$ & $\begin{array}{c}3 \\
(10.0 \%)\end{array}$ & $\begin{array}{c}7 \\
(23.3 \%)\end{array}$ & $\begin{array}{c}0 \\
(0 \%)\end{array}$ \\
\hline
\end{tabular}

F-Females; $M$-Males; * $-P<0.05$ vs. the control group without taking into account the gender.

Thus, the data analysis showed statistically significant differences between the frequency of both homozygous and heterozygous genotypes of studied SNPs (rs3812718 and rs16851603) in FS children, compared to children without FS who suffered from HTS $(\mathrm{P}<0.05)$.

For carriers of rs16851603, the risk of FS development in the main group was statistically significant higher and made up 1.14 vs. 0.28 in the control group, respectively $(\mathrm{OR}=4.12$, $95 \%$ CI: $1.96-8.69 ; \mathrm{P}<0.05)$. It was also found, that in the main group the risk of FS development was statistically significantly higher in heterozygous carriers of rs3812718 and constituted to 7.86 vs. 0.32 in the control group, respectively $(\mathrm{OR}=24.44,95 \%$ CI: 9.46-63.14; $\mathrm{P}<0.05)$.

In view of the foregoing, it can be argued that polymorphisms rs16851603 and rs3812718 of the SCN1A gene are prognostically unfavorable biological risk factors (predictors) for FS development. At the same time, children carrying the polymorphic allele $166909544 T$ (rs3812718) are at greatest risk for FS development, which is consistent with previous studies showing the role of this locus in the GEFS+ 
development and other idiopathic epilepsies in a follow-up period. ${ }^{(9)}$

\section{Discussion}

The proinflammatory cytokine IL1B belongs to a large family of cytokines, including also proinflammatory cytokine IL1A and anti-inflammatory IL1RA. IL1B modulates cell proliferation, induces other cytokines, ${ }^{(10)}$ and can serve as an endogenous pyrogen ${ }^{(11)}$ It is important to note that bacterial lipopolysaccharides stimulate production of IL1B, not only by macrophages on the periphery, but also by microglia, astrocytes and some neurons of the CNS. Increased IL1B level due to infection process leads to increased CNS hyperexcitability and excitotoxicity through $\mathrm{Ca}^{2+}$, glutamatergic, and GABAergic mechanisms. ${ }^{(12)}$ The $I L 1 B$ gene, encoding proinflammatory cytokine IL1B, plays a role in the inflammatory response and fever development, ${ }^{(11)}$ and is a genetic predictor of mesial temporal sclerosis and symptomatic temporal mediobasal epilepsy. ${ }^{(7,13,14)}$ Our investigation of rs 1143634 polymorphism of IL1B gene, demonstrating a high risk of FS development in carriers of high-producing allele $C$, is consistent with the data in the literature, according to which the $C T$ genotype of rs1143634 leads to a higher IL1B, cerebrospinal, fluid/serum ratio and is associated with increased risk of developing posttraumatic epilepsy.(15) Moreover, the data shown by Diamond and coauthors, suggests that $T T$ homozygotes are relatively protected from posttraumatic epilepsy, ${ }^{(15)}$ which in our study corresponds to the low risk of FS development.

Some researchers hold the opinion that an imbalance in the levels of pro- and anti-inflammatory cytokines during the infectious process can contribute to FS development. ${ }^{(16)}$ In our study, we paid special attention to revealing the etiological role of infectious pathogens, especially herpes viruses, in FS development. According to the literature, about a third of all FS in children are associated with the persistence of HHV-6. (17) We discovered IgG antibodies against HHV-6 in 46.4\% (13/28) of examined patients with recurrent FS, more often than antibodies against other investigated herpes viruses. It is well known that maximum concentration of this virus is found in the most epileptogenic areas of CNS, particularly, in the temporal lobe and adjacent regions of the brain, where HHV-6 causes dysfunction of astroglia. Epileptogenic effect on sensitive neurons in the hippocampus ultimately leads to sclerosis of its structures with the subsequent development of mediobasal temporal epilepsy.(17) Thus, the prolonged persistence of HHV-6 in the child's organism can be considered as a trigger for the development of recurrent FS. We have shown that the persistence of CMV-infection was most frequently revealed in the carriers of a homozygous genotype for high-producing allelic variant 3954CC. The mention of CMV in the development of convulsive states was noted in single articles, but generalized data on the role of this pathogen in FS development were not found. ${ }^{(18)}$

An important role in FS development is given to the change in the electrical membrane potential of neuronal, voltage-dependent ion channels. Some stuties have suggested that a moderate violation of the permeability of sodium channel
NaV1.1, as a result of mutation or SNP of SCN1A gene, can predetermine FS development, ${ }^{(19)}$ especially in family cases. Normally, RNA encoding NaV1.1, NaV1.2 and NaV1.3 channels undergoes a controlled change in the alternative splicing of exon 5, which has a striking effect on the activation of a potential-dependent sodium channel. ${ }^{(20)}$ Regulation of this alternative splicing is interrupted due to SNP rs3812718, which is associated with a change in the response to antiepileptic drugs and the risk of FS development in European population. ${ }^{(21,22)}$ In our research into the rs3812718 allele and genotype distribution, the frequency of the low-producing mutant allele $T$ in the main group was statistically significantly higher $(\mathrm{P}=0.001)$. At the same time, the carriage of heterozygous genotype $C T$ demonstrated a direct relationship with FS development $(\mathrm{OR}=44.95 ; \mathrm{P}=0.000)$. An interesting opinion was discussed by M.Hong that heterozygous associations for genetic variation for genes coding membrane receptors can occur and may result in multiple actions that affect the phenotype of interest (e.g., differential effects of membrane trafficking for receptor protein heterodimers vs. homodimers). ${ }^{(15)}$

In general, FS are a common multifactorial disease, and only the interaction of genetic and environmental factors can induce FS development. ${ }^{(23)}$ Despite the fact that the issues of treatment and prevention of FS have been discussed for several decades, many aspects of genetics and preventive measures of FS recurrences and their transformation into afebrile epileptical seizures remain debatable.

\section{Conclusion}

Our research complements the previously published data on the problem of FS and confirms the feasibility of a personalized approach to the management of children with this pathology. This approach allows us to optimize the tactics (clinical examination, treatment, primary and secondary prevention) for managing young children with FS and to reduce the risk of symptomatic focal epilepsy in a followup period. ${ }^{(13)}$ We propose that children with FS who are both carriers of the association of high-producing allelic variants of $I L 1 B$ gene and the active herpesvirus mixed-infection need the preventive treatment for FS and joint observation by a pediatrician, a pediatric infectionist, and a neurologistepileptologist. In addition, obtained data indicate the importance of detecting rs3812718 polymorphism in children with FS and the necessity of dispensary observation of them by a children's neurologist (or a neurologist-epileptologist in the presence of indications), along with conducting video electroencephalography monitoring for timely diagnosis of the debut of afebrile seizures and personalized selection of antiepileptic drugs with the rejection of sodium channel blockers due to the previously shown pharmacoresistance to this group of drugs in the carriers of allele 166909544T (rs3812718) and high risk of AED-induced seizure aggravation.

\section{Competing interests}

The authors declare that they have no competing interests. 


\section{Sources of funding}

This study was funded by the Krasnoyarsk Regional Fund for Support of Scientific and Scientific-technical Activity” (additional agreement №03/15 from 12.05.2015).

\section{Acknowledgements}

We would like to thank A.V. Muravyova, Department of Medical Genetics at V.F. Voyno-Yasenetsky Krasnoyarsk State Medical University, for technical assistance.

\section{References}

1. Kaputu Kalala Malu C, Mafuta Musalu E, Dubru JM, Leroy P, Tomat AM, Misson JP. [Epidemiology and characteristics of febrile seizures in children]. Rev Med Liege. 2013;68(4):180-5. [Article in French].

2. Krikova EV, Val'dman EA, Avakian GN, Andreev IaA, Denisov EV, Rider FK, et al. [Association study of the SCN1 gene polymorphism and effective dose of lamotrigine]. $\mathrm{Zh}$ Nevrol Psikhiatr Im S S Korsakova. 2009;109(10):57-62. [Article in Russian].

3. Abe $T$, Seo $T$, Ishitsu $T$, Nakagawa $T$, Hori $M$, Nakagawa K. Association between SCN1A polymorphism and carbamazepine-resistant epilepsy. Br J Clin Pharmacol. 2008;66(2):304-7. doi: 10.1111/j.1365-2125.2008.03203.x.

4. Patterson JL, Carapetian SA, Hageman JR, Kelley KR. Febrile seizures. Pediatr Ann. 2013;42(12):249-54. doi: 10.3928/00904481-20131122-09.

5. Lehtimäki KA, Keränen T, Palmio J, Peltola J. Levels of IL-1beta and IL-1ra in cerebrospinal fluid of human patients after single and prolonged seizures. Neuroimmunomodulation . 2010;17(1):19-22. doi: 10.1159/000243081.

6. Chou IC, Lin WD, Wang CH, Chang HT, Tsai CL, Fuu JT. Interleukin (IL)-1beta, IL-1 receptor antagonist, IL-6, IL-8, IL-10, and tumor necrosis factor alpha gene polymorphisms in patients with febrile seizures. J Clin Lab Anal. 2010;24(3):1549. doi: 10.1002/jcla.20374.

7. Heida JG, Moshe SL, Pittman QJ. The role of interleukin1 beta in febrile seizures. Brain Dev. 2009;31(5):388-93. doi: 10.1016/j.braindev.2008.11.013.

8. Fallah R, AkhavanKarbasi S, Golestan M. Afebrile seizure subsequent to initial febrile seizure. Singapore Med J. 2012;53(5):349-52.

9. Hirose S, Mohney RP, Okada M, Kaneko S, Mitsudome A. The genetics of febrile seizures and related epilepsy syndromes. Brain Dev. 2003;25(5):304-12.

10. Nakayama J, Arinami T. Molecular genetics of febrile seizures. Epilepsy Res. 2006;70 Suppl 1:S190-8.

11. Serdaroglu G, Alpman A, Tosun A, Pehlivan S, Ozkinay F, Tekgul H, et al. Febrile seizures: interleukin-1 beta and interleukin-1 receptor antagonist polymorphisms.
Pediatr Neurol. 2009;40(2):113-6. doi: 10.1016/j. pediatrneurol.2008.10.004.

12. Zhu G, Okada M, Yoshida S, Mori F, Ueno S, Wakabayashi $\mathrm{K}$, et al. Effects of interleukin-1beta on hippocampal glutamate and GABA releases associated with $\mathrm{Ca}^{2+}$-induced $\mathrm{Ca}^{2+}$ releasing systems. Epilepsy Res. 2006;71(2-3):107-16.

13. Panina Yu, Muravyova A, Shnayder N, Terskova N. Role of polymorphisms of gene $I L 1 \beta$ in parainfectional symptomatic temporal lobe epilepsy development. Eur J Paediatr Neurol. 2014;18:820. DOI: http://dx.doi.org/10.1016/j. ejpn.2014.06.008.

14. Wu ZQ, Sun L, Sun YH, Ren C, Jiang YH, Lv XL. Interleukin 1 beta $2511 \mathrm{C} / \mathrm{T}$ gene polymorphism and susceptibility to febrile seizures: a meta-analysis. Mol Biol Rep. 2012;5:5401-7.

15. Diamond ML, Ritter AC, Failla MD, Boles JA, Conley YP, Kochanek PM, et al. IL-1b associations with posttraumatic epilepsy development: A genetics and biomarker cohort study. Epilepsia. 2014;55(7):1109-19. doi: 10.1111 /epi. 12628.

16. Zerr DM, Frenkel LM, Huang ML, Rhoads M, Nguy L, Del Beccaro MA, et al. Polymerase chain reaction diagnosis of primary human herpesvirus- 6 infection in the cute care setting. J Pediatr. 2006;149(4):480-5.

17. Epstein LG, Shinnar S, Hesdorffer DC, Nordli DR, Hamidullah A, Benn EKT, et al. Human herpesvirus 6 and 7 in febrile status epilepticus: the FEBSTAT study. Epilepsia. 2012;53(9):1481-8. doi: 10.1111/j.1528-1167.2012.03542.x.

18. Iannetti P, Fiorilli M, Sirianni MC, Paná A, Aiuti F. Nonfebrile seizures after febrile convulsions: possible role of chronic cytomegalovirus infection. J Pediatr. 1982;101(1):27-31. 19. Baum L, Haerian BS, Ng HK, Wong VC, Ng PW, Lui $\mathrm{CH}$. Case-control association study of polymorphisms in the voltage-gated sodium channel genes $S C N 1 A, S C N 2 A$, $S C N 3 A, S C N 1 B$, and $S C N 2 B$ and epilepsy. Hum Genet. 2014;133(5):651-9. doi: 10.1007/s00439-013-1405-1.

20. Gazina EV, Richards KL, Mokhtar MB, Thomas EA, Reid CA, Petrou S. Differential expression of exon 5 splice variants of sodium channel $\alpha$ subunit mRNAs in the developing mouse brain. Neuroscience. 2009;166(1):195-200. doi: 10.1016/j. neuroscience.2009.12.011.

21. Vadlamudi L, Milne RL, Lawrence K, Heron SE, Eckhaus J, Keay D, et al. Genetics of epilepsy: the testimony of twins in the molecular era. Neurology. 2014;83(12):1042-8. doi: 10.1212/WNL.0000000000000790.

22. Haerian BS, Baum L, Kwan P, Tan HJ, Raymond AA, Mohamed Z. SCN1A, SCN2A and SCN3A gene polymorphisms and responsiveness to antiepileptic drugs: a multicenter cohort study and meta-analysis. Pharmacogenomics. 2013;14(10):1153-66. doi: 10.2217/ pgs.13.104.

23. Stroganova MA, Shnayder NA, Martynova GP, Diuzhakova AV. [Epidemiology of febrile seizures in children (review)]. In the World Scientific Discovery, Series B. 2014;2(2):70-77.[Article in Russian]. 